\title{
Advanced DInSAR analysis on mining areas: La Union case study (Murcia, SE Spain)
}

\author{
G. Herrera $^{\mathrm{a}, *}$, R. Tomás ${ }^{\mathrm{b}}$, J.M. Lopez-Sanchez ${ }^{\mathrm{c}}$, J. Delgado ${ }^{\mathrm{d}}$, \\ J.J. Mallorqui ${ }^{\mathrm{e}}, \mathrm{S}$. Duque ${ }^{\mathrm{e}}$, J. Mulas ${ }^{\mathrm{a}}$ \\ ${ }^{a}$ Recursos Minerales, Riesgos Geológicos y Geoambiente, Instituto Geológico y Minero de España (IGME), \\ Ministerio de Ciencia y Tecnología, c/ Ríos Rosas 23, E-28003 Madrid, Spain \\ ${ }^{\mathrm{b}}$ Departamento de Ingeniería de la Construcción, Obras Públicas e Infraestructura Urbana, Escuela Politécnica Superior, \\ Universidad de Alicante P.O. Box 99, E-03080 Alicante, Spain \\ c Departamento de Física, Ingeniería de Sistemas y Teoría de la Señal (DFISTS), Escuela Politécnica Superior, \\ Universidad de Alicante, P.O. Box 99, E-03080 Alicante, Spain \\ d Departamento de Ciencias de la Tierra y Medioambiente. Facultad de Ciencias, \\ Universidad de Alicante, P.O. Box 99, E-03080 Alicante, Spain \\ e Departament de Teoria del Senyal i Comunicacions, Universitat Politècnica de Catalunya, c/Jordi Girona, \\ 1-3, Ed. D-3, E-08034, Barcelona, Spain
}

Received 31 July 2006; received in revised form 21 December 2006; accepted 2 January 2007

Available online 16 January 2007

\begin{abstract}
The town of La Union (SE, Spain) is located within a metal mining area that has been exploited since the Roman period. This historic exploitation has left behind a high concentration of abandoned underground mining galleries. Currently, an industrial area is subsiding due to the collapse of one of these galleries in May 1998. In this paper, an advanced Differential Interferometry SAR (DInSAR) method called the Coherent Pixels Technique (CPT) has been used to study the subsidence phenomena for two time intervals, from January 1998 to December 2000, and from March 2003 to December 2004. DInSAR-derived deformation maps have enabled the detection and monitoring of different deformation processes that affect several locations within the study area. By comparing these results with the underground mining galleries map, a clear relationship between their presence and the subsidence has been proved. Deformation values retrieved with DInSAR between April 2003 and December 2004 have been compared with the topographical leveling network measurements performed in this same period, providing an absolute average difference of $0.7 \mathrm{~cm}$ with a standard deviation of $0.5 \mathrm{~cm}$. Results obtained in the city of La Union have shown that the advanced DInSAR technique is able to provide very useful spatial and temporal deformation data for the measurement of small scale subsidence throughout short time periods. This technique has enabled the temporal evolution of the phenomena in the city of La Unión to be studied and understanding of subsidence to be expanded beyond the limits of a deployed topographical control network, in a more cost effective way than classical methods.
\end{abstract}

(C) 2007 Elsevier B.V. All rights reserved.

Keywords: Differential SAR Interferometry (DInSAR); Subsidence; Collapse; Mining; Urban areas

* Corresponding author.

E-mail addresses: g.herrera@igme.es (G. Herrera), roberto.tomas@ua.es (R. Tomás),juanma.lopez@ua.es (J.M. Lopez-Sanchez), jose.delgado@ua.es (J. Delgado), mallorqui@tsc.upc.edu (J.J. Mallorqui).

\section{Introduction}

Ground subsidence involves the settlement of the ground surface and can affect wide areas. Civil buildings 
in these areas do not always withstand these vertical deformations, and may suffer severe structural damage. Different types of ground subsidence are present in several areas of the Region of Murcia (SE Spain). Ground subsidence induced by overexploitation of aquifers has affected the metropolitan area of Murcia since 1992 (Mulas et al., 2003; Aragón et al., 2004; Martínez et al., 2004) and has been monitored by Differential SAR Interferometry (IGME 2004; Tomás et al., 2005). Subsidence associated with the collapse of underground cavities is generally more localized than the former, but exhibits a greater destruction capacity due to the velocity of this phenomenon. This type of subsidence has occurred in the industrial area of Lo Tacón in the city of La Union (Murcia, SE Spain) since May 1998, as a result of the collapse of an abandoned underground mine gallery.

La Unión is a metal mining area that has been exploited since the Roman period. The mineral extraction method varied over time from open pit to underground mining (S. XVIII-XIX) and back to open pit mining (s. XX). Due to this historic exploitation, a high concentration of abandoned underground mining galleries is found in this area. A fast and sudden collapse of several underground mining cavities occurred on 2nd May 1998 in Lo Tacón industrial area, which is located in the southwest part of the city of La Unión. This event caused the complete structural failure of one building and severe damage to surrounding constructions, thus triggering considerable social alarm. A topographical leveling network was set up in June 1998 and a maximum accumulated settlement of $-50 \mathrm{~cm}$ was measured in July 1999 within the subsidence bowl area, which had appeared after the collapse (Fig. 1). (Rodriguez-Estella et al., 2000).

Differential Interferometry with Synthetic Aperture Radar (DInSAR) has become over the last decade an important remote sensing tool for the estimation of temporal and spatial surface motions due to subsidence (Galloway et al., 1998; Ferretti et al., 2000; Colesanti et al., 2001; Ferretti et al., 2001; Berardino et al., 2002) and particularly in mining subsidence cases (Carnec and Delacourt, 2000; Wegmuller et al., 2004; Raucoules et al., 2003; Chang and Rizos, 2004; Crosetto et al., 2005, Colesanti et al., 2005). DInSAR offers several important advantages when compared to classical methods used to measure subsidence deformations. For example, DInSAR provides high spatial coverage in urban areas whilst other common techniques, such as the Differential Global Positioning System (DGPS) and instrumental methods, are able to measure ground deformations only at discrete points, not over a wide and continuous area. As for leveling methods, such techniques can also cover a whole territory but benchmark density is generally far lower than in DInSAR techniques. In addition, complete leveling surveys cannot be repeated frequently as the cost of carrying out the measurements is very high. Several studies have compared DInSAR with traditional geodetic techniques concluding that the former can be used to set up a monthly or annual monitoring service at a lower cost (Wegmuller et al., 1999; Tomás, 2004).

In this paper, mining subsidence in the city of $\mathrm{La}$ Unión is studied by means of an advanced DInSAR technique known as the Coherent Pixels Technique (Mora, 2004; Mora et al., 2003). This technique has been applied to an area measuring $12 \mathrm{~km} \times 8 \mathrm{~km}$ and is centered on the mining district of La Unión. A total of 38 Single Look Complex (SLC) images from January 1998 to December 2004, acquired by ERS-1, ERS-2 and ENVISAT satellites, have been used and divided into two subsets as will be explained.

DInSAR-derived deformation values have been imported into a Geographical Information System (GIS) for data interpretation and compared with underground mine gallery maps and available topographic measurements from both periods. This analysis has allowed the monitored area to be expanded, thus providing a better understanding of the deformation phenomenon as a result of the joint use of both monitoring techniques.

\section{Description of the study area}

\subsection{Location and description of the problem}

The city of La Unión is located at the centre of a mining area consisting of a rectangular surface of $10 \mathrm{~km} \times 5 \mathrm{~km}$ that historically accumulated the greatest lead and zinc $(\mathrm{Pb}-\mathrm{Zn})$ mineralizations of the Betic Cordillera. Mining started with the Romans and activity peaked in the second half of the 19th century and throughout the 20th century until the 1980's (Manteca and Ovejero, 1992). All of this historic activity has shaped a region with many underground cavities due to the abandoned mine galleries. Some studies have revealed that underground cavity rates, i.e. the ratios of the void subsoil volume over the total subsoil volume, vary from $57 \%$ to $97 \%$ with an average value of $67 \%$ (Rodriguez-Estella et al., 2000).

On 2nd May 1998, a fast and sudden collapse of several underground mining galleries became apparent at surface level with the total failure of an industrial building in Lo Tacón industrial area, located towards the 

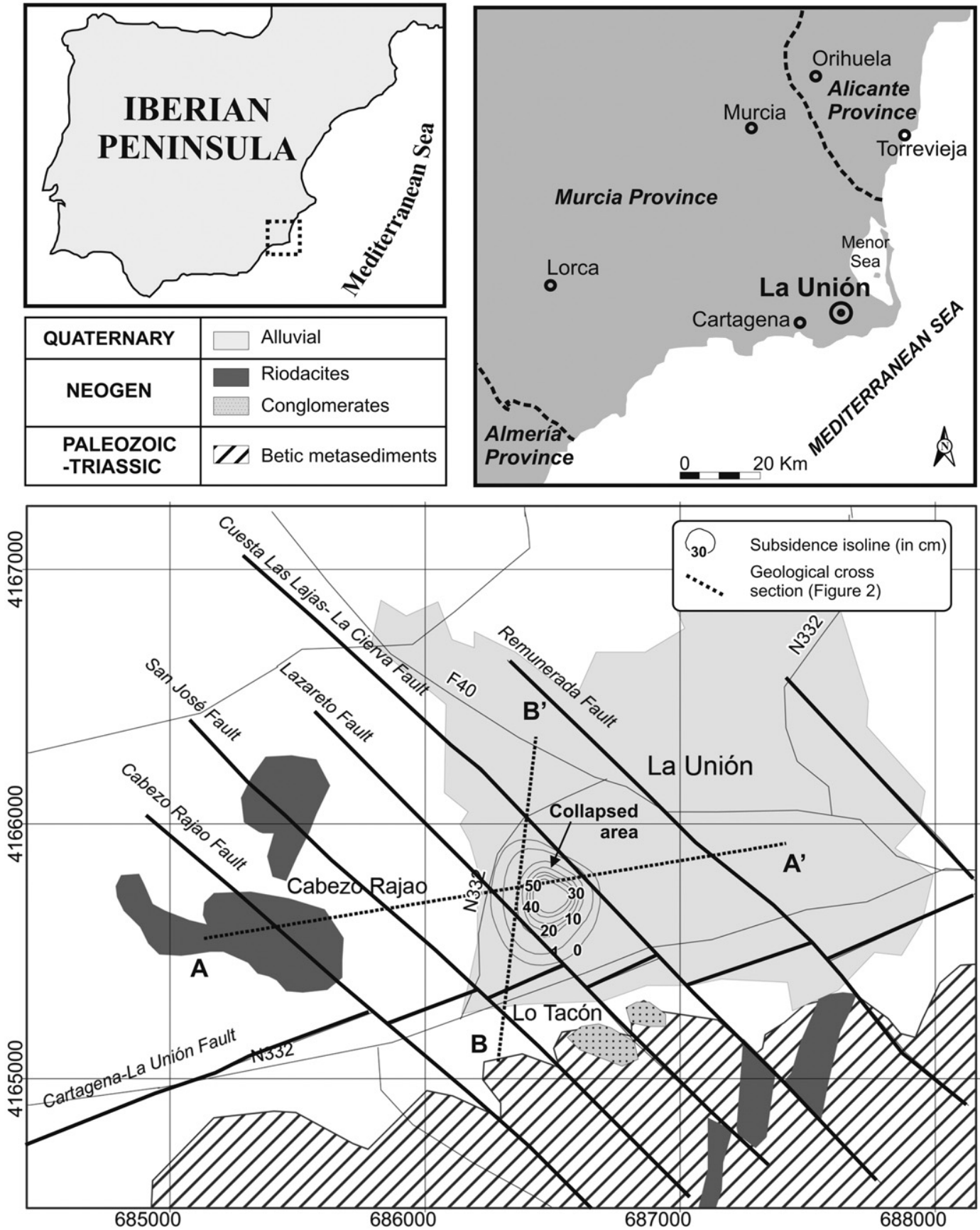

Fig. 1. Location of the study area and geological scheme of the city of La Unión with superposition of subsidence isolines for the period 1998-1999 after the collapse of May 1998 (based on Rodriguez-Estella et al., 2000; IGME, 1996).

southwest of the city of La Unión (Fig. 1). Residual settlements followed this episode producing severe damages in the buildings within a $295 \mathrm{~m} \times 323 \mathrm{~m}$ subsidence bowl area. Considerable social alarm followed this episode and the Regional Government requested a field study of the ground movement, involving an underground cavity inventory, geotechnical borehole analysis and topographical leveling monitoring. The collapsed volume is estimated at around $20,810 \mathrm{~m}^{3}$, which is only $7.5 \%$ of the mapped underground cavities existing in the study area, which are at a depth of $80 \mathrm{~m}$ to $254 \mathrm{~m}$ from the surface (Fig. 2). 


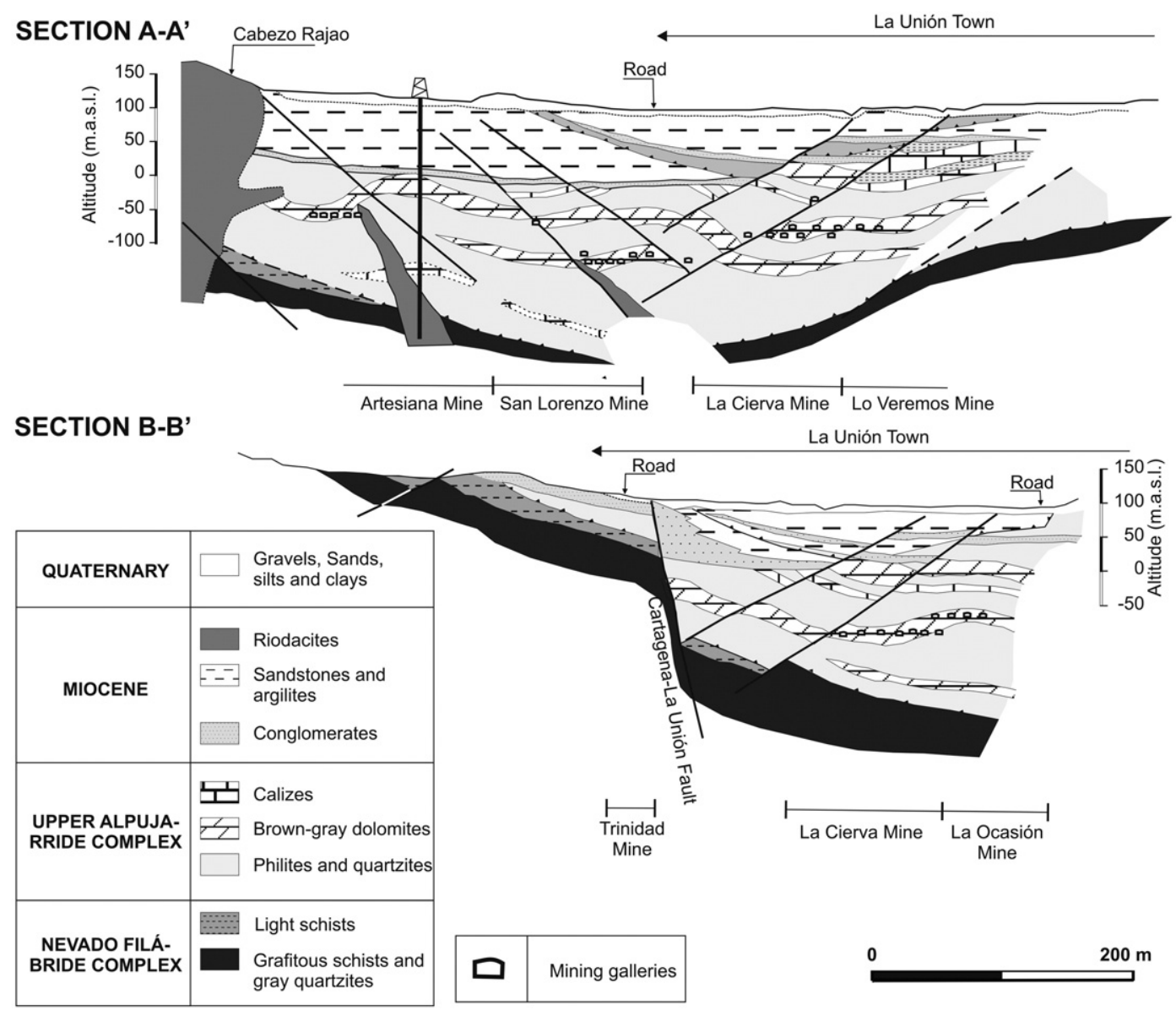

Fig. 2. Geological cross sections $\mathrm{AA}^{\prime}$ and $\mathrm{BB}^{\prime}$ with indication of underground mining cavities location (based on Rodriguez-Estella et al., 2000; IGME, 1996).

\subsection{Geological setting}

From a geological viewpoint, the study area is located in the Sierra de Cartagena, in the Internal Zones of the Betic Cordillera. It is characterized by a series of alpine superposed napes (Nevado Filábride and Alpujárride complexes) affected by a decreasing metamorphism towards the top. These materials, after a significant erosive phase, were covered by a postorogenic, Neogene series of sedimentary rocks, after which there was an important fracturation phase, followed by volcanism and uplift, giving rise to the present-day relief (García-Tortosa et al., 2000). Intrusive magmatism from Miocene volcanism outcrop in the form of mounts, also known as "Cabezos". Finally, a thin level of quaternary alluvial deposits, made of sand, silt and clays, covers older materials (Figs. 1 and 2).

From a structural point of view, the study area is close to the intersection of two regional faults: Cartagena-La Unión (strike N70E) and Cuesta Las-
Lajas-La-Cierva (N130E) (Figs. 1 and 2), which are the main faults of the two existing sets of fracture systems in the area. The geological and structural complexity of the region configures a set of independent blocks with no hydrodynamic/hydrological relation between them, so they do not constitute a single aquifer. Most of the geological units are not permeable, i.e. those formed by schistes, phyllites and marls. Only Alpujarride marbles, detritic Miocene rocks and quaternary formations are permeable. Pumping tests carried out in well points have demonstrated that permeability values are always low (IGME, 1996). This fact and the absence of a significant compressible level confirm that subsidence due to water table variations is not expected in this area.

\subsection{Previous research and available data}

The published available data consist of a seismotectonic analysis that establishes a correlation between the 
occurrence of the cavity collapse and an earthquake occurred on 2nd of May $1998\left(m_{\mathrm{b}}=2.3\right)$, with its epicentre located in Torrepacheco (Murcia), close to the study zone (Rodriguez-Estella et al., 2000). Measurements taken after the collapse in Lo Tacón, for a time span of a year (June 1998-June 1999), revealed a constant displacement rate of $-4.8 \mathrm{~cm} /$ month and an accumulated deformation of $-53.6 \mathrm{~cm}$ in the centre of the subsidence bowl area. At the edges of this area, a constant displacement rate of $-0.5 \mathrm{~cm} /$ month and an accumulated deformation of $-5.4 \mathrm{~cm}$ were observed in June 1999. In April 2003, the topographical leveling network was updated, enlarging the monitoring area. These new data showed that deformation velocities were reduced in this second stage, decreasing to maximum values in the range of $-5 \mathrm{~cm} /$ year (CIMA, 2005). Deformations measured by field instrumentation and deformations estimated by DInSAR are compared in the following sections.

\section{DInSAR as ground motion recognition and monitoring method}

\subsection{Overview of methodology}

In this study, an advanced DInSAR algorithm known as the Coherent Pixels Technique (CPT) has been used to obtain ground displacements from satellite radar images. A detailed description of the whole algorithm can be consulted in Mora et al. (2003) and Mora (2004). The generation of DInSAR deformation maps involves several complex steps: image focusing from raw data, image co-registration, satellite orbit calculation, gener- ation of differential interferograms, CPT algorithm application and result geocoding from radar coordinates to Universal Traverse Mercator (UTM). The evaluation of the error associated with this technique depends on external issues different to the algorithm, such as the amount of available SAR images, baseline distribution, Doppler centroid differences, control points, etc. Previous studies (Mallorqui, 2003; Mora et al., 2003; Lanari et al., 2004; Tomás et al., 2005) have compared available ground control measurements with obtained DInSAR results, stating that an error of $\pm 5 \mathrm{~mm}$ in the estimation of the non-linear term of deformation can be assumed in the worst case. Linear velocities can be estimated with accuracies of over $1 \mathrm{~mm} /$ year. However, these values strongly depend on the number of images and the conditions in which they were obtained as regards baselines and Doppler distribution, selected pixel density and how they are connected, and the presence of atmospheric disturbances. More recently, Casu et al. (2006) estimated a sub-centimetric accuracy with a standard deviation of approximately $\pm 5 \mathrm{~mm}$, consistently in both the SAR/leveling and SAR/GPS comparisons, using the Small Baseline Subset (SBAS) approach, which is quite similar to CPT.

\subsection{Data set and processing details}

Two independent data sets of 24 and 14 SLC SAR images each, acquired by the European Space Agency (ESA) remote sensing satellites ERS-1, ERS-2 and ENVISAT, between January 1998 and December 2000, and April 2003 and December 2004, respectively, have been used in this study (Table 1). A crop of about

Table 1

ERS and ENVISAT SAR SLC data used for both analysed periods, 1998-1999 and 2003-2004

\begin{tabular}{|c|c|c|c|c|c|c|c|c|c|c|c|}
\hline \multicolumn{8}{|c|}{ Period 1998-2000 } & \multicolumn{4}{|c|}{ Period 2003-2004 } \\
\hline No & Orbit & Satellite & Date & No & Orbit & Satellite & Date & No & Orbit & Satellite & Date \\
\hline 1 & 14,348 & ERS2 & $17 / 01 / 1998$ & 15 & 24,869 & ERS2 & $22 / 01 / 2000$ & 1 & 41,903 & ERS2 & $26 / 04 / 2003$ \\
\hline 2 & 15,350 & ERS2 & 28/03/1998 & 16 & 25,370 & ERS2 & $26 / 02 / 2000$ & 2 & 43,907 & ERS2 & $09 / 08 / 2003$ \\
\hline 3 & 16,853 & ERS2 & $11 / 07 / 1998$ & 17 & 25,871 & ERS2 & $01 / 04 / 2000$ & 3 & 8536 & ENVISAT & $18 / 10 / 2003$ \\
\hline 4 & 17,855 & ERS2 & 19/09/1998 & 18 & 26,372 & ERS2 & $06 / 05 / 2000$ & 4 & 44,909 & ERS2 & $22 / 11 / 2003$ \\
\hline 5 & 18,857 & ERS2 & 28/11/1998 & 19 & 26,873 & ERS2 & $10 / 06 / 2000$ & 5 & 9538 & ENVISAT & $27 / 12 / 2003$ \\
\hline 6 & 20,360 & ERS1 & 13/03/1999 & 20 & 27,374 & ERS2 & $15 / 07 / 2000$ & 6 & 10,039 & ENVISAT & $31 / 01 / 2004$ \\
\hline 7 & 20,861 & ERS2 & 17/04/1999 & 21 & 27,875 & ERS2 & $19 / 08 / 2000$ & 7 & 10,540 & ENVISAT & $06 / 03 / 2004$ \\
\hline 8 & 21,362 & ERS2 & $22 / 05 / 1999$ & 22 & 28,376 & ERS2 & $23 / 09 / 2000$ & 8 & 11,041 & ENVISAT & $10 / 04 / 2004$ \\
\hline 9 & 41,903 & ERS1 & $30 / 07 / 1999$ & 23 & 28,877 & ERS2 & $28 / 10 / 2000$ & 9 & 47,414 & ERS2 & $15 / 05 / 2004$ \\
\hline 10 & 22,364 & ERS2 & 31/07/1999 & 24 & 29,378 & ERS2 & $02 / 12 / 2000$ & 10 & 12,043 & ENVISAT & $19 / 06 / 2004$ \\
\hline 11 & 42,536 & ERS2 & 03/09/1999 & & & & & 11 & 48,917 & ERS2 & $28 / 08 / 2004$ \\
\hline 12 & 22,865 & ERS2 & 04/09/1999 & & & & & 12 & 49,418 & ERS2 & $02 / 10 / 2004$ \\
\hline 13 & 23,867 & ERS2 & 13/11/1999 & & & & & 13 & 14,047 & ENVISAT & $06 / 11 / 2004$ \\
\hline 14 & 24,368 & ERS2 & $18 / 12 / 1999$ & & & & & 14 & 14,548 & ENVISAT & $11 / 12 / 2004$ \\
\hline
\end{tabular}

The images correspond to track 466 and frame 2853. 
$12 \mathrm{~km} \times 8 \mathrm{~km}$ was selected from the original images, corresponding to the mining district of La Unión (Fig. 3).

From the whole set of inteferograms formed by all possible pairs of images, only those with a perpendicular spatial baseline smaller than $130 \mathrm{~m}$, a temporal baseline shorter than 900 days and a relative Doppler centroid difference below $250 \mathrm{~Hz}$ were selected. Due to the multi-look factor of $20 \times 4$ pixels (azimuth $\times$ range) the final resolution is degraded to $80 \times 80 \mathrm{~m}$. The external DEM used to cancel the topographic component of the interferometric phase has a resolution of $25 \times 25 \mathrm{~m}$ and belongs to the cartographic numeric database E5 from CARTOMUR (Cartographical Service of the Region of Murcia) which contains information from the Regional Topographical Map 1:5000 elaborated by CIMA (Ministry of Industry and Environment of the Region of Murcia).

Coherent pixels where the deformation is computed are selected in two independent stages. In the first stage, pixels with a coherence greater than 0.5 in more than $50 \%$ of the interferograms are chosen. These are meshed using Delaunay triangulations, with arcs no longer than $900 \mathrm{~m}$. In a second stage, pixels with coherences comprised between 0.3 and 0.5 in more than $50 \%$ of the interferograms are added to the original selection and the whole process, including triangulation, is repeated. The newly added pixels, which have a lower phase quality, take advantage of the previously-selected nodes, whose values had been fixed, during the model adjustment and integration of the deformation velocity and DEM error. This iterative process, which is called multi-layer, could be extended to lower coherence values (Blanco et al., 2006).

\section{Results and discussion}

Several deformation processes of a different nature have been detected in the study area (Fig. 3). In this paper, analysis is focused on subsidence due to underground mining activity in the city of La Union (a in Fig. 3). Results have been compared with underground mining gallery maps as well as with the available topographical leveling network data. Other detected deformation areas correspond to open pit mining slope instabilities and are currently the object of research (b in Fig. 3). The absence of vegetation, the existence of

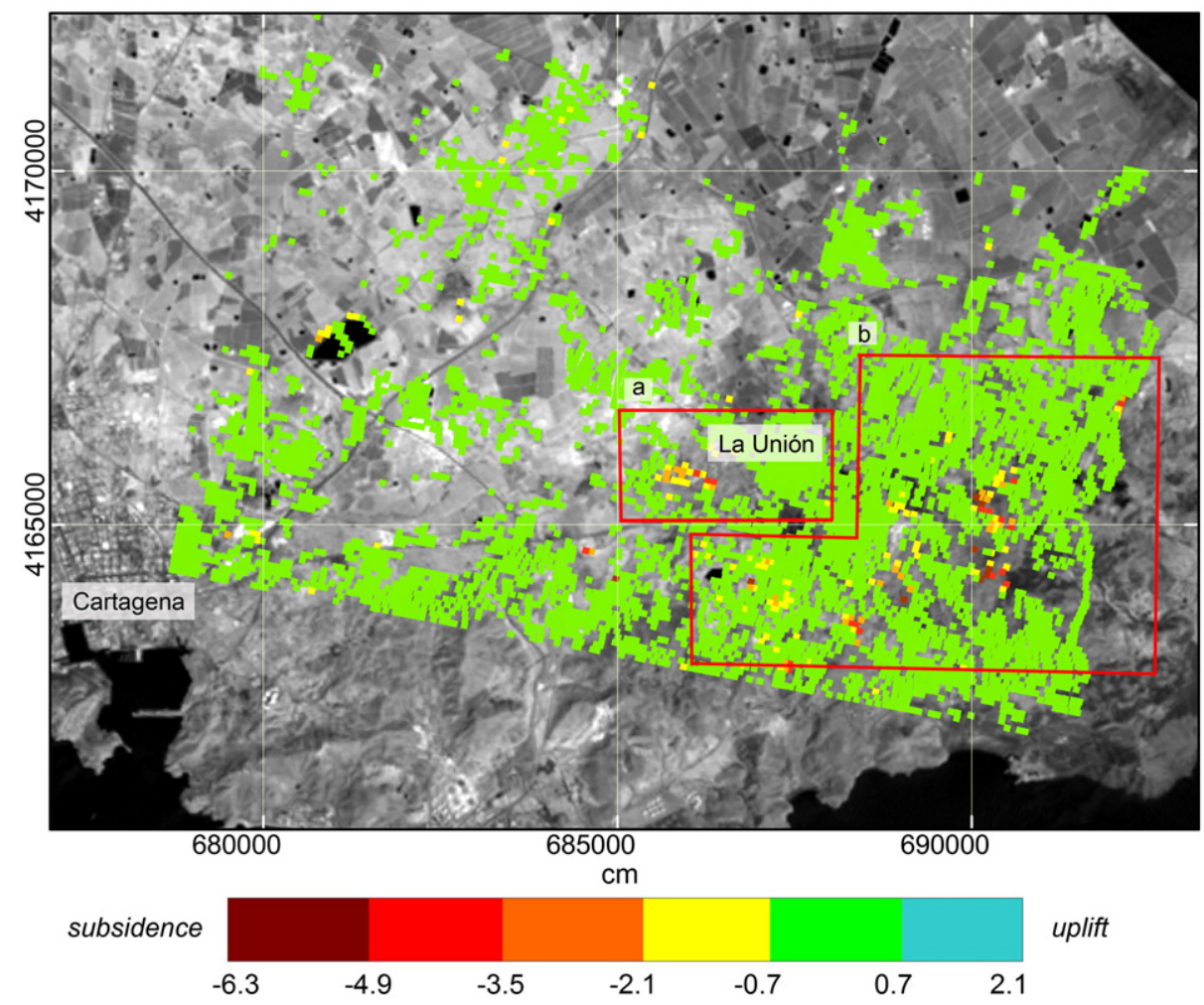

Fig. 3. DInSAR detected deformation areas between January 1998 and December 2000 for the whole $12 \mathrm{~km} \times 8 \mathrm{~km}$ study area in the landsat image: a) La Unión city area; b) open pit mining area. 
buildings and massive rock outcrops in the study area as well as the short time span have enabled a successful correlation between SAR images providing good coherence values, and hence, a good estimation of the deformation phenomena. For the whole $12 \mathrm{~km} \times 8 \mathrm{~km}$ area the average spatial density is 54 coherent pixels $\mathrm{km}^{-2}$, and 84 coherent pixels $\mathrm{km}^{-2}$ for the $3 \mathrm{~km} \times 3 \mathrm{~km}$ test area in the city of La Unión (Fig. 3a). Nevertheless, in the first period a lack of coherence is observed in the subsidence bowl area which appeared after the collapse. This is due to the great displacement occurred, which exceeded the limit posed by the sampling theorem in the detection of unambiguous deformation. Phase measurements are affected by an intrinsic $2 \pi$ ambiguity, which
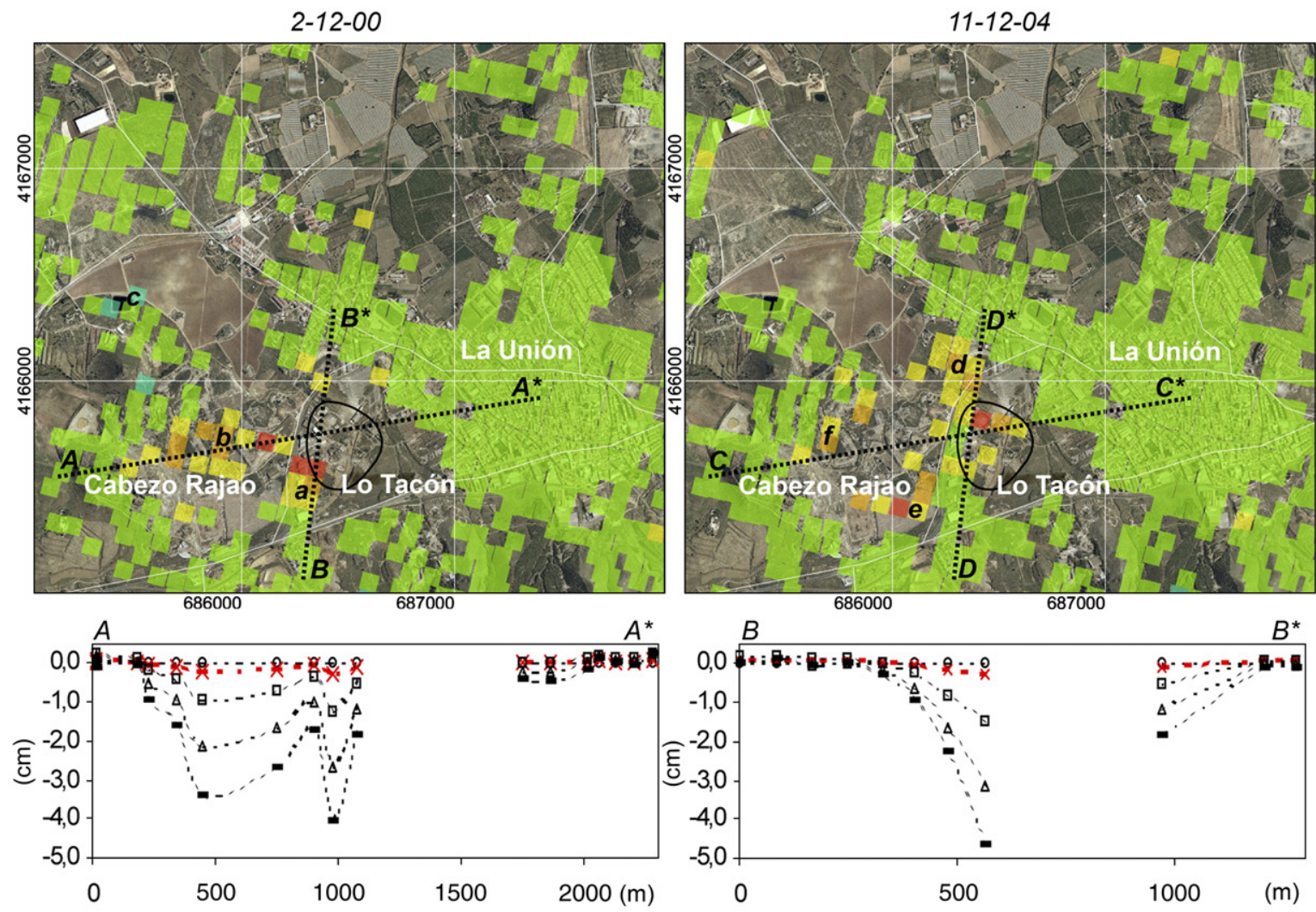

..... 17-1-98

$\cdots \times \cdot \cdot 28-3-98$

… ... 28-11-98

$\cdots \Delta \cdots 13-11-99$

$\cdots=2-12-00$
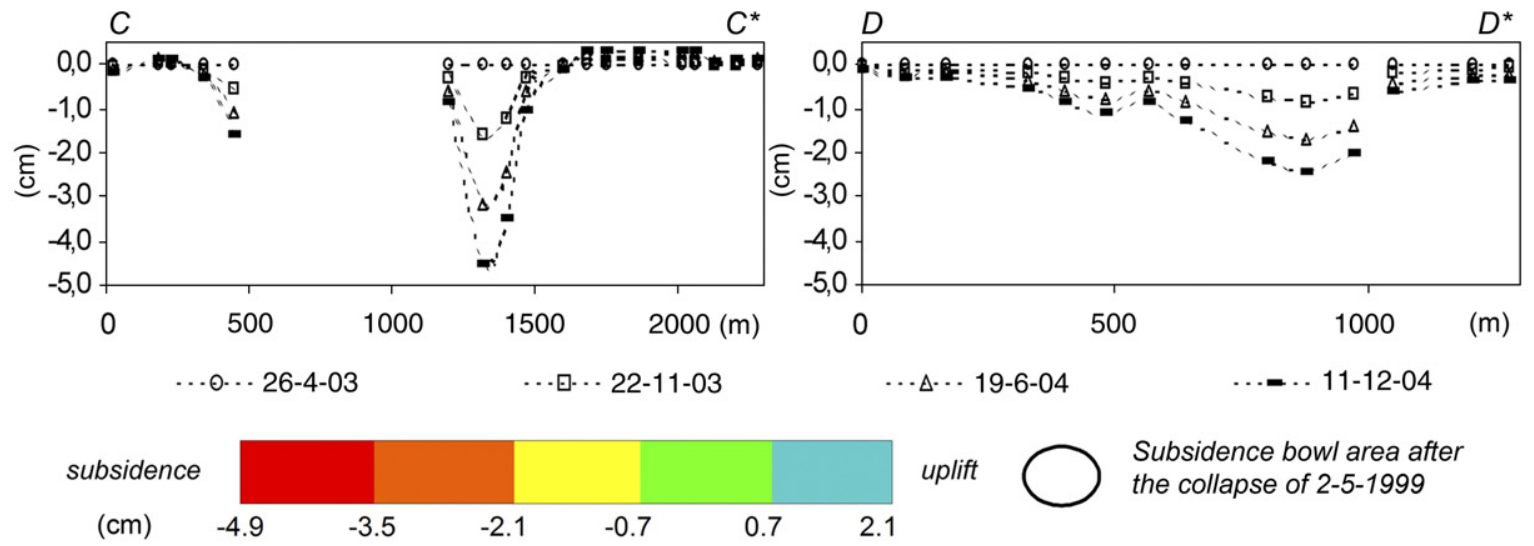

uplift

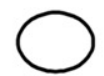

Subsidence bowl area after

the collapse of 2-5-1999

Fig. 4. Accumulated deformation at the end of the period between January 1998 and December 2000, and between April 2003 and December 2004 , respectively. $\mathrm{AA}^{\prime}, \mathrm{BB}^{\prime}, \mathrm{CC}^{\prime}$ and $\mathrm{DD}^{\prime}$ : profiles of the displacement evolution with time for both analysed periods. 

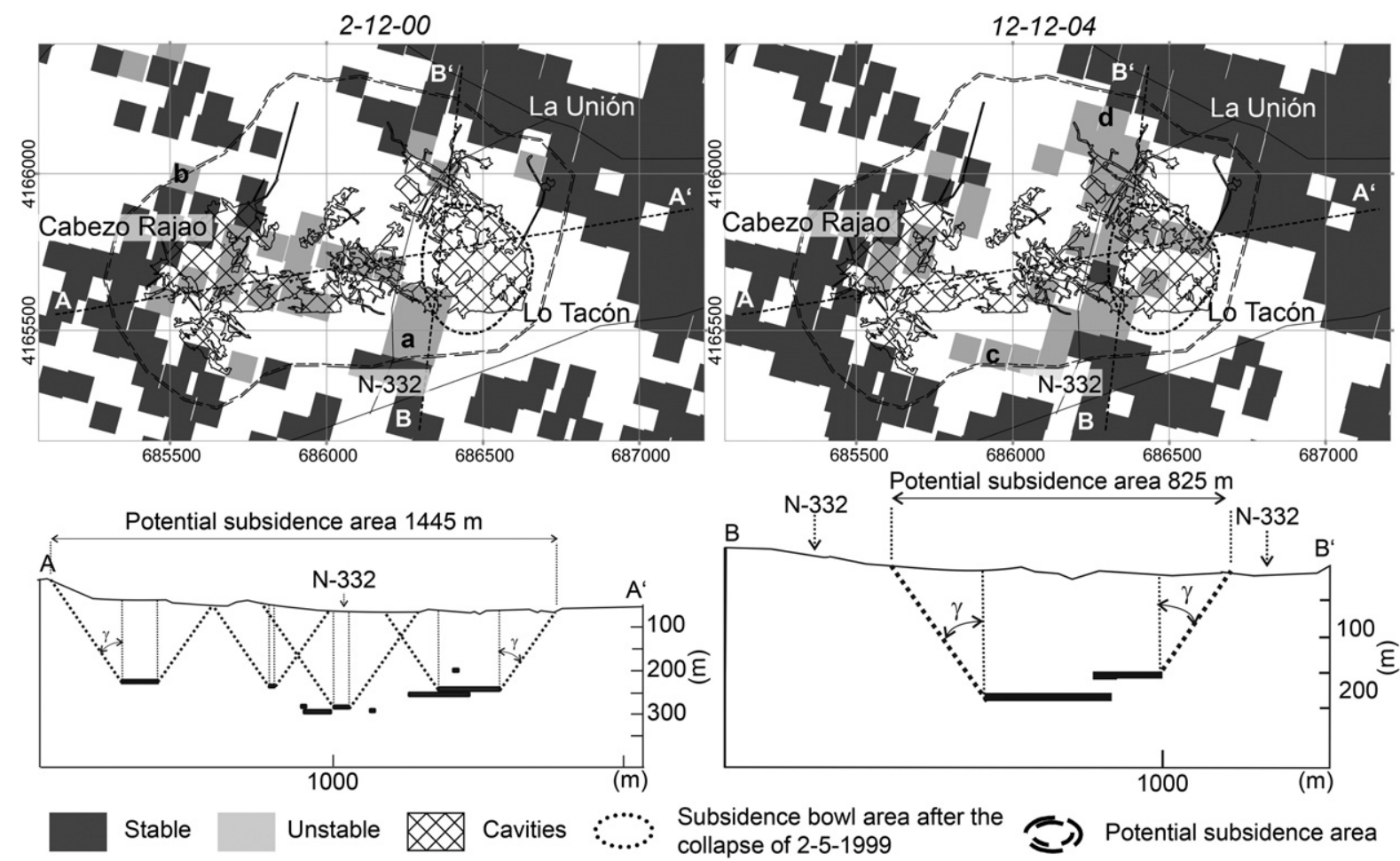

Fig. 5. Deformed surface in both analysed periods overlapped with underground cavities map.

corresponds, for ERS SAR, to $\lambda / 2=2.83 \mathrm{~cm}$ along the line of sight (LOS). Therefore, aliasing affects data characterized by more than $\lambda / 2=2.83 \mathrm{~cm}$ along LOS displacement in the 35 day ERS revisiting time. This limit can be overcome if the DInSAR analysis is carried out exploiting the spatial correlation of the deformation phenomenon at-hand, as long as the spatial gradient of the displacement effect is not too great.

\subsection{Spatial and temporal evolution of the subsidence retrieved by DInSar}

In the period between January 1998 and December 2000, residual settlements have been recorded outside the limits of the subsidence bowl area detected after the collapse. At the end of this period, the south of Lo Tacón (a in Fig. 4) accumulated deformations vary from $-0.6 \mathrm{~cm}$ to $-4.6 \mathrm{~cm}$, with maximum velocities of $-2.3 \mathrm{~cm} /$ year. Whereas in the northern edge of this area limiting La Unión urban area, deformations vary from $-0.4 \mathrm{~cm}$ to $-1.2 \mathrm{~cm}$, with maximum velocities of $-0.6 \mathrm{~cm} /$ year. Another detected settlement location is Cabezo Rajao area (b in Fig. 4), where deformations vary from $-0.3 \mathrm{~cm}$ to $2.7 \mathrm{~cm}$, and maximum velocities reach $-1.4 \mathrm{~cm} /$ year. This is an area with isolated mining constructions and where massive rock outcrops provide coherent pixels. There is also a small uplifted area of a few pixels towards the North from Cabezo Rajao (c in Fig. 4), where accumulated deformations vary from $+0.9 \mathrm{~cm}$ to $+1.2 \mathrm{~cm}$ and maximum velocities of $+0.5 \mathrm{~cm}$.

The DInSAR measurements after the collapse in May 1998, are affected by aliasing due to the high displacement rate observed by topographical leveling within the subsidence bowl area. Nevertheless, outside the limits of this area, a displacement of a few milimetres in April 1998 ( $\mathrm{AA}^{\prime}$ and $\mathrm{BB}^{\prime}$ profiles in Fig. 4), showed evidence of the LOS deformation phenomenon 1 month before the May 1998 collapse event. For the rest of the period, a continuous low displacement rate has been observed in the nonmonitored areas of Lo Tacón and Cabezo Rajao.

From April 2003 to December 2004 subsidence has been detected in Lo Tacón industrial area, as deformation rates have been significantly reduced with respect to the first period. At the northern edge of Lo Tacón and bordering with La Union city (d in Fig. 4), accumulated settlements below $-1.6 \mathrm{~cm}$ and velocities of $-0.7 \mathrm{~cm} /$ year are found. Maximum settlements of $-4.2 \mathrm{~cm}$ and velocities of $-2.1 \mathrm{~cm} /$ year are located within the subsidence bowl area which appeared after the collapse 
of 2-5-1998. The south of Lo Tacón, which was an active area in the former period, is currently stabilised. However, near to this area (e in Fig. 4), there are accumulated maximum settlements of $-3.7 \mathrm{~cm}$ and velocities of $-1.6 \mathrm{~cm} /$ year. El Cabezo Rajao area (f in Fig. 4) shows accumulated settlements of $-2.7 \mathrm{~cm}$ and velocities of up to $-1.6 \mathrm{~cm} /$ year.

The temporal evolution analysis for this period retrieved with DInSAR shows that the south of Lo Tacón area has stabilised with respect to the first period. Settlement in the subsidence bowl area after the collapse has decreased with respect to the first period, and aliasing does not prevent the estimation of LOS deformation (profiles $\mathrm{BB}^{\prime}$ and $\mathrm{DD}^{\prime}$ in Fig. 4). Subsidence at Cabezo Rajao is still active, but, as can be seen by comparing profiles AA' and CC', a lower concentration of coherent pixels has been found (Fig. 4).

\subsection{Comparison with underground mining gallery maps}

By overlapping the accumulated deformation map for December 2000 (Fig. 4) with the underground mining cavities map, settlement areas with mapped underground mining cavities in the Cabezo Rajao area can be correlated. Fig. 5 allows for the visualization in grey, of those unstable pixels that have experienced deformation in any of the two analysed periods, whereas the dark grey colour represents those stable pixels that have not experienced any significant movement. The same correlation cannot be observed in the industrial area of Lo Tacón, since no coherent pixels are found within the subsidence bowl area after the collapse of 2-5-1998. Nevertheless, the achieved results indicate that the collapse in Lo Tacon was followed by residual settlements affecting a larger area than that of the subsidence bowl area, which extends towards the Cabezo Rajao area.

The accumulated deformation observed in December 2004 (Fig. 4) shows that the rapid subsidence registered between 1998 and 1999 evolved into a slower consolidation process. A clear correlation is found between settlement in the subsidence bowl area and the presence of underground mining galleries (Fig. 5). The absence of underground mining galleries below La Union urban area supports the conclusion that subsidence will not affect buildings within this city. The same correlation can be observed in the centre of Cabezo Rajao, which presents a high concentration of abandoned underground mining galleries and is still affected by subsidence phenomena.

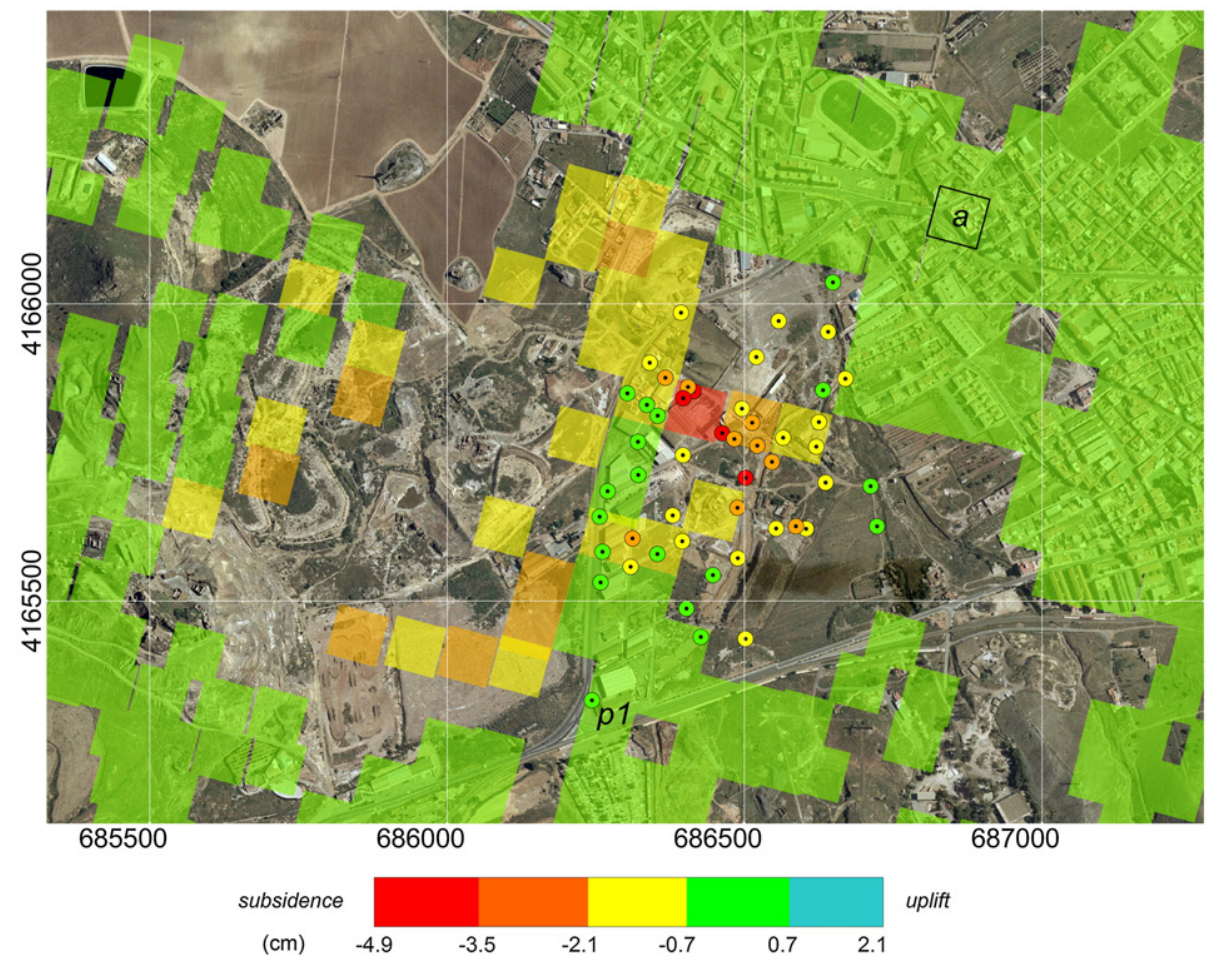

Fig. 6. DInSAR and topographical leveling (CIMA, 2005) accumulated deformation in Lo Tacón industrial area in July 2004. 
In both analysed periods, it can be observed that several unstable pixels (a, b, c and d in Fig. 5) do not correspond to the mining extraction area in the transverse perpendicular direction. These pixels are located in a range from 70 to $140 \mathrm{~m}$ beyond the edge of the mine, and underground working levels are located at a depth of between 150 and $250 \mathrm{~m}$ from the surface $\left(\mathrm{AA}^{\prime}\right.$ and $\mathrm{BB}^{\prime}$ profiles in Fig. 5). Taking into account these parameters, the angle of draw, $\gamma$, can be estimated. This angle measured from the vertical at the edge of the extraction area defines the potential subsidence area, which is equal to the subsidence area plus an area surrounding the former. The calculated angle of draw for these pixels varies from 20 to $33^{\circ}$, which correspond to that described in literature and which varies from 25 to $35^{\circ}$ in most instances (Bello, 1995; Crowell, 1995). Taking into account the depth of mining cavities and the least favorable estimated angle of draw at $33^{\circ}$, a $1444 \mathrm{~m} \times 825 \mathrm{~m}$ potential subsidence area has been calculated. This area is 12 times greater than the $295 \mathrm{~m} \times 323 \mathrm{~m}$ subsidence bowl area which was monitored by topographical leveling methods after the 2-5-1998 collapse. Fig. 5 confirms that the areas of Lo Tacón and Cabezo Rajao are included within this area, which borders with La Unión urban area towards the North.

\subsection{Comparison with available topographical leveling data from 2003 to 2004}

In this period, topographical leveling data provided 57 measurement points located towards the Southwest of the city of La Union, in the industrial area of Lo Tacón. These data show accumulated vertical deformation varying from $-5.3 \mathrm{~cm}$ to $+1 \mathrm{~cm}$, with an error of $\pm 0.2 \mathrm{~cm}$ and an average value of $-1.2 \mathrm{~cm}$. The reference SAR stable point is pixel "a" in Fig. 6 and "P1" is the reference control point for the topographical leveling network. The DInSAR-retrieved deformation value in the correspondent pixel of $\mathrm{P} 1$ is $-0.1 \mathrm{~cm}$. Both datasets are corregistered with respect to this point and an acceptable correlation between both datasets has been observed (Fig. 6). A total of 35 ground control points correspond to coherent pixels. Ground control points which do not coincide with coherent pixels are located in unbuilt areas, where soils absent of rocky outcrops do not provide good coherence values.

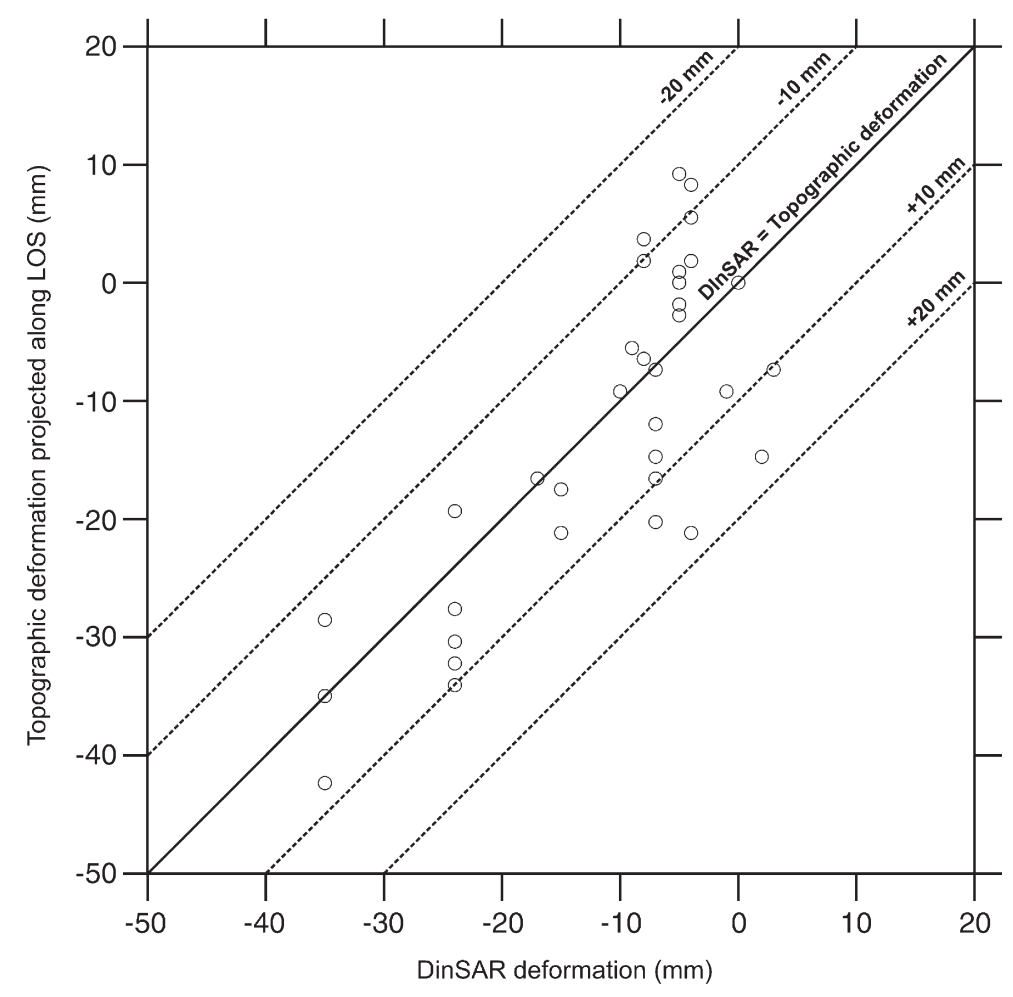

Fig. 7. Comparison between DInSAR estimated deformations and topographical leveling-measured deformations projected along the Line of Sight (LOS). 
The available topographical leveling data were obtained from two campaigns performed in April 2003 and July 2004, whereas DInSAR settlements were retrieved from a dataset including 14 ERS and ENVISAT images acquired from April 2003 to December 2004. The comparison has been done with the accumulated deformation datasets obtained from both techniques in July 2004. The absolute differences vary from 0 to $1.9 \mathrm{~cm}$, the average absolute difference value is $0.7 \mathrm{~cm}$ and the standard deviation is $0.5 \mathrm{~cm}$ (Fig. 7). Each estimate of the deformation corresponds to a pixel of $80 \times 80 \mathrm{~m}$ in size, and, as can be seen in Fig. 6, several ground control points are located on the same pixel. Taking into account the most similar deformation value of the ground control points with respect to the pixel they are included in, the average absolute difference drops to $0.5 \mathrm{~cm}$ and the standard deviation to 0.3 .

\section{Conclusions}

A DInSAR analysis of the residual settlements which followed the collapse of mine underground cavities in the industrial area of La Union on 2nd May 1998 has been presented. This study has provided information about the spatial distribution and magnitude of the consolidation process experienced in a period with incomplete instrumental data. For this purpose, two independent data sets of 24 and 14 SLC SAR images each, acquired between January 1998 and December 2000, and April 2003 and December 2004, respectively, have been used.

In most of the DInSAR monitoring area, different unknown deformation processes affecting several locations other than the initially targeted study area have been detected and monitored. Cabezo Rajao is a subsiding area close to the city of La Unión that had not been monitored previously. Slope instabilities have been detected in an open pit mining area close to the city of La Unión and are currently the object of research. Finally, no subsidence phenomenon has been detected in the urban area of the city of La Union.

By overlapping the accumulated deformation maps with the underground mining galleries map, a correlation has been found. The angle of draw and potential subsidence area have been calculated taking into account DInSAR-observed deformation values with respect to underground mining cavity depths. The least favorable estimated angle of draw is $33^{\circ}$ and $1444 \mathrm{~m} \times 825 \mathrm{~m}$ of the potential subsidence area coincides with the Lo Tacón and Cabezo Rajao areas, which border with La Unión urban area towards the North.
In the period 1998 to 2000 , the DInSAR technique cannot estimate deformation within the collapse area of influence in Lo Tacón, due to the high displacement rate observed by topographical leveling after the 2-5-1998 collapse. Nevertheless, at the edge of this area, a displacement of few millimeters in April 1998 provided evidence of the LOS deformation phenomenon one month before the May 1998 collapse event. For the whole period, an average continuous low displacement rate of $-2.3 \mathrm{~cm} /$ year has been detected in the area surrounding the subsidence bowl after the collapse, highlighting unknown and non-monitored settlement in Cabezo Rajao.

A good agreement has been found between results derived from DInSAR and available topographical leveling data for the period April 2003 to December 2004. For this period, DInSAR-retrieved values show maximum accumulated deformations of $-4.6 \mathrm{~cm}$ and subsidence velocities of $-2.3 \mathrm{~cm} /$ year. The absolute differences with respect to the topographical leveling network from July 2004, vary from 0 to $1.9 \mathrm{~cm}$ and the absolute mean difference is $0.7 \mathrm{~cm}$ and $0.5 \mathrm{~cm}$ the standard deviation value.

In the near future, the analysis of all available ascending and descending satellite radar images should be useful to detect collapse precursors before January 1998 and possible horizontal movements associated with mining subsidence phenomena. This information will complement on-site traditional techniques thus improving the understanding of the subsidence phenomena of the city of La Union in a cost effective way.

\section{Acknowledgements}

The European Space Agency (ESA) has provided all SAR images used in this work in the framework of the project EO Cat.1-2494. This work has been partially financed by the Spanish Geological and Mining Institute (IGME) within project 2004051, by the Spanish Ministry of Education and Science and EU FEDER within projects TEC2005-06863 and BTE2002-12456$\mathrm{E}$, and by the Generalitat Valenciana within projects GV04B/556, GV06/179 and GRUPOS03/085. The Cartographical Service (CARTOMUR) of the Industry and Environment Regional Ministry of Murcia (CIMA) has provided DEM data and aerial photographs used in this work. Topographical leveling campaigns from March 2003 to December 2004 in the city of La Union have been provided by Mining and Energy Direction from the Industry and Environment Regional Ministry of Murcia (CIMA) and were performed by the Polytechnic University of Cartagena (UPCT). 


\section{References}

Aragón, R., García-Aróstegui, J.L., Lambán, J., Hornero, J., Fernández-Grillo, A.I., 2004. Impacto de la explotación intensiva de aguas subterráneas en la ciudad de Murcia (España), análisis hidrogeológico. Proceedings of 23th Int. Congress of IAHALHSUD, 2004, Zacatecas, Mexico, pp. 2622-2624.

Blanco, P., Mallorqui, J.J., Duque, S., Navarrete, D., 2006. Proc. Advances on DInSAR with ERS and ENVISAT data using the Coherent Pixels Technique (CPT). Proceedings of IGARSS 2006, Denver, Colorado.

Bello, A., 1995. Aspectos gráficos en la predicción de subsidencia. Ph. D. Thesis, Universidad de Oviedo, 200 pp.

Berardino, P., Fornaro, G., Lanari, R., Sansosti, E., 2002. A new algorithm for surface deformation monitoring based on small baseline differential SAR interferograms. IEEE Transactions on Geoscience and Remote Sensing 40, 2375-2383.

Carnec, C., Delacourt, C., 2000. Three years of mining subsidence monitored by SAR interferometry, near Gardanne, France. Journal of Applied Geophysics 43, 43-54.

Casu, F., Manzo, M., Lanari, R., 2006. A quantitative assessment of the SBAS algorithm performance for surface deformation retrieval from DInSAR data. Remote Sensing of Environment 102, $195-210$.

CIMA, 2005. Topographical leveling data of Lo Tacón industrial area in April 2003 and July 2004. Dirección de Industria, Energía y Minas de la Consejería de Industria y Medio Ambiente de la Región de Murcia. 20 pp.

Chang, H.C., Rizos, C., 2004. Application of repeat-pass DInSAR and GIS for underground mine subsidence monitoring. Proceedings of IGARSS 2004, Anchorage, Alaska, vol. 5, pp. 2815-2818.

Colesanti, C., Ferreti, A., Prati, C., Rocca, F., 2001. Comparing GPS, optical leveling and permanent scatterers. Proceedings of IGARSS 2001, Sydney, Australia, vol. 6, pp. 2622-2624.

Colesanti, C., Le Mouelic, S., Bennani, M., Carnec, C., Ferreti, A., 2005. Detection of mining related ground instabilities using the Permanent Scatterers technique - a case study in the east of France. International Journal of Remote Sensing 26 (1), 201-207.

Crosetto, M., Crippa, B., Biescas, E., 2005. Early detection and indepth analysis of deformation phenomena by radar interferometry. Engineering Geology 79, 81-91.

Crowell, D.L., 1995. The hazards of mine subsidence. Ohio Division of Geological Survey, pp. 1-5.

Ferretti, A., Prati, C., Rocca, F., 2000. Nonlinear subsidence rate estimation using permanent scatterers in differential SAR interferometry. IEEE Transactions on Geoscience and Remote Sensing 38, 2202-2212.

Ferretti, A., Prati, C., Rocca, F., 2001. Permanent scatterers in SAR interferometry. IEEE Transactions on Geoscience and Remote Sensing 39, 8-20.

Galloway, D.L., Hudnut, K.W., Ingebritsen, S.E., Philips, S.P., Peltzer, G., Rogez, F., 1998. Detection of aquifer system compaction and land subsidence using interferometric synthetic aperture radar, Antelope Valley, Mojave Desert, California. Water Resources Research 34, 2573-2585.

García-Tortosa, F.J., López-Garrido, A.C., Sanz de Galdeano, C., 2000. Las unidades de Cabo Tiñoso y Peñas Blancas: revisión y caracterización estratigráfica de las unidades Alpujarrides del sector entre Mazarrón y Cartagena (Murcia, España). Estudios Geológicos 56, 31-40.
IGME, 1996. Recuperación de Usos de la bahía de Portman. Estudio Geológico e Hidrogeológico de la Sierra Minera de Cartagena. Instituto Geológico y Minero de España, Madrid, vol. 1. 330 pp.

IGME, 2004. Estimación de la subsidencia del Área Metropolitana de Murcia mediante Interferometría Radar. Instituto Geológico y Minero de España, Madrid. 38 pp.

Lanari, R., Mora, O., Manuta, M., Mallorquí, J.J., Berandino, P., Sansosti, E., 2004. A small baseline DIFSAR approach for investigating deformations on full resolution SAR interferograms. IEEE Transactions on Geoscience and Remote Sensing 7, 1377-1386.

Mallorqui, J.J., 2003. CPT: Development of Algorithms for the Exploitation of ERS-ENVISAT Using the Coherent Píxels Technique (ESA), Contract No. 17584/03/I-LG OT:911584.

Manteca, J.I., Ovejero, G., 1992. Los yacimientos Zn, Pb, Ag - Fe del distrito minero de La Unión - Cartagena, Bética Oriental. Recursos Minerales en España, pp. 1085-1102.

Martínez, M., Mulas, J., Herrera, G., Aragón, R., 2004. Efectos de una subsidencia moderada por extracción de agua subterránea en Murcia, España. Proceedings of 23th Congress of IAH-ALHSUD, Zacatecas, Mexico, pp. 249-252.

Mora, O., 2004. Advanced differential SAR techniques for detection of terrain and building displacements. Ph. D. Thesis, Polytechnic University of Catalonia, $182 \mathrm{pp}$.

Mora, O., Mallorquí, J.J., Broquetas, A., 2003. Linear and nonlinear terrain deformation maps from a reduced set of interferometric SAR images. IEEE Transactions on Geoscience and Remote Sensing 41, 2243-2253.

Mulas, J., Aragón, R., Martínez, M., Lambán, J., García-Arostegui, J.L., Fernández-Grillo, A.I., Hornero, J., Rodríguez, J., Rodríguez, J.M., 2003. Geotechnical and hydrological analysis of land subsidence in Murcia (Spain). Proceedings. 1st International Conference on Groundwater in Geological Engineering, Bled, Slovenia, vol. 50, pp. 249-252.

Raucoules, D., Maisons, C., Carnec, C., Le Mouelic, S., King, C., Hosford, S., 2003. Monitoring of slow ground deformation by ERS radar interferometry on the Vauvert salt mine (France). Comparison with ground-based measurement. Remote Sensing of Environment 88, 468-478.

Rodriguez-Estella, T., Manteca, J.L., García, C., 2000. Subsidencia minera, en relación con sismotectónica, en La Unión (Murcia). Geotemas 1, 150-153.

Tomás, R., 2004. Aplicación de Interferometría SAR Diferencial a la Subsidencia de la Ciudad de Murcia. Universidad de Alicante, Tesina. 133 pp.

Tomás, R., Márquez, Y., Lopez-Sanchez, J.M., Delgado, J., Blanco, P., Mallorqui, J.J., Martinez, M., Herrera, G., Mulas, J., 2005. Mapping ground subsidence induced by aquifer overexploitation using advanced Differential SAR Interferometry: Vega Media of the Segura River (SE Spain) case study. Remote Sensing of the Environment 98, 269-283.

Wegmuller, U., Strozzi, T., Bitelli, G., 1999. Validation of ERS differential SAR interferometry for landsubsidence mapping: the Bologna case study. Proceedings of IGARSS 1999, Hamburg, Germany, vol. 2, pp. 1131-1133.

Wegmuller, U., Werner, C., Strozzi, T., Wiesmann, A., 2004. Monitoring mining-induced surface deformation. Proceedings of IGARSS 2004, Anchorage, Alaska, vol. 3, pp. 1933-1935. 